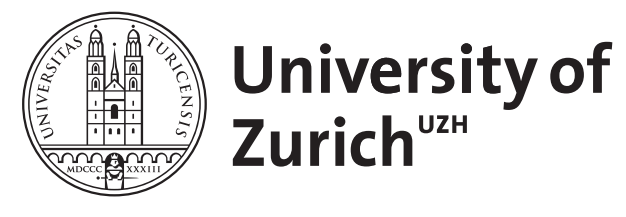

\title{
Long-term consequences of polycystic ovary syndrome on cardiovascular risk
}

\author{
Rizzo, M ; Berneis, K ; Spinas, G A ; Rini, G B ; Carmina, E
}

\begin{abstract}
Most available data suggest that the prevalence of cardiovascular diseases in women with polycystic ovary syndrome (PCOS) is smaller than expected based on risk calculations during fertile years; therefore, more studies are needed on long-term cardiovascular consequences. Evidence is accumulating that postmenopausal women with PCOS have an increased risk of cerebrovascular events and cardiovascular morbidity. These events are partially related to persisting hyperandrogenism but are mostly correlated with excessive body weight (mainly visceral obesity); this suggests that our best long-term strategy is to ensure that women with PCOS are informed about their high risk for metabolic and cardiovascular diseases.
\end{abstract}

DOI: https://doi.org/10.1016/j.fertnstert.2008.09.070

Posted at the Zurich Open Repository and Archive, University of Zurich

ZORA URL: https://doi.org/10.5167/uzh-17402

Journal Article

Accepted Version

Originally published at:

Rizzo, M; Berneis, K; Spinas, G A; Rini, G B; Carmina, E (2009). Long-term consequences of polycystic ovary syndrome on cardiovascular risk. Fertility and Sterility, 91(4 Supp):1563-1567.

DOI: https://doi.org/10.1016/j.fertnstert.2008.09.070 
Running title: Cardiovascular risk in PCOS

\title{
LONG-TERM CONSEQUENCES OF POLYCYSTIC OVARY SYNDROME ON CARDIOVASCULAR RISK
}

\author{
Manfredi Rizzo, MD, PhD ${ }^{\text {a; }}$ Kaspar Berneis, $\mathrm{MD}^{\mathrm{b}}$; Giatgen Spinas, MD ${ }^{\mathrm{b}}$; \\ Giovam Battista Rini, MD; ${ }^{\mathrm{a}}$, Enrico Carmina, $\mathrm{MD}^{\mathrm{a}}$
}

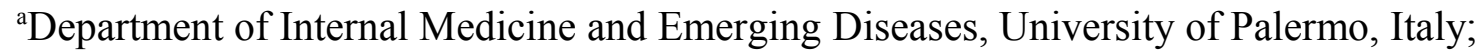
${ }^{\mathrm{b} C l i n i c s}$ for Endocrinology, Diabetes \& Clinical Nutrition, University Hospital Zurich, Switzerland.

\section{Corresponding author for reprints:}

Manfredi Rizzo, MD, PhD

Department of Internal Medicine and Emerging Diseases

University of Palermo

Via del Vespro, $141-90127$

Palermo - Italy

Ph. $+39(091) 6552945$

Fax: $+39(091) 6552982$

E-mail: 


\section{CAPSULE}

Postmenopausal women with PCOS have increased cerebro-vascular events and cardiovascular morbidity. Our best long-term strategy is information, acknowledging women with PCOS of their risk for metabolic and cardiovascular diseases. 


\begin{abstract}
Most available data suggest that the prevalence of cardiovascular diseases in women with polycystic ovary syndrome (PCOS) is smaller than what expected on the basis of the risk calculation during fertile age; therefore, we need many more studies on their long term cardiovascular consequences although evidence is accumulating that women with PCOS at postmenopausal age have an increase in cerebro-vascular events and in cardiovascular morbidity. These events are partially related to the persisting hyperandrogenism but are mostly correlated to the excessive body weight (mainly to the visceral obesity); this suggests that our best long term strategy is the information, acknowledging women with PCOS of their high risk for metabolic and cardiovascular diseases.
\end{abstract}

Key Words: polycystic ovary syndrome; cardiovascular risk; menopause; events. 


\section{Introduction}

Fertile women with polycystic ovary syndrome (PCOS) have increased cardiovascular risk and this finding has been consistently confirmed across several geographic areas and ethnic groups (1). Yet, the risk for cardiovascular diseases in women with PCOS at postmenopausal age is largely unknown. Women with PCOS are more likely than normally cycling women to have insulin resistance, central adiposity, dyslipidemia and hypertension (2).

On the basis of such elevated prevalence of metabolic and cardiovascular risk factors, a clear and significant increase in cardiovascular outcome was expected in postmenopausal age. However, there is still not clear evidence for this and, although new studies are showing increased cardiovascular morbidity (see below), most available data suggest that the prevalence of cardiovascular diseases in women with PCOS is smaller than what expected on the basis of the risk calculation during fertile age (3).

\section{Markers of cardiovascular risk in PCOS}

Several markers of cardiovascular risk have been found to be altered in PCOS. Serum markers include C-reactive protein (4-6), adiponectin (7,8), plasminogen activator-1 (9), Von Willebrand factor (10), endothelin-1 (11), homocysteine (12) and markers of oxidative stress (13) and the majority of the studies have demonstrated that such abnormalities were related to insulin resistance and obesity in women with PCOS (14). Further, dyslipidemia is very common and may represent the most common metabolic abnormality in PCOS, with a prevalence of up to $70 \%$ according to the National Cholesterol Education Program criteria $(\mathbf{1 4}, \mathbf{1 5})$. Dyslipidemia usually include low HDL-cholesterol levels and elevated triglyceride concentrations while increased LDL and total cholesterol have been also found but with a lower prevalence (14). Beyond plasma lipids, women with PCOS have lower LDL size due to 
increased levels of atherogenic small, dense LDL [16-18] and recent studies have suggested the "quality" and not only the "quantity" of LDL is strongly associated with cardiovascular risk (19).

Other studies have evaluated the relationships between PCOS and cardiovascular diseases using markers of subclinical atherosclerosis. These studies focused on the arterial wall and the myocardium and included functional studies (i.e. those investigating ventricular function, arterial stiffness and endothelial function) and morphological studies (i.e. those investigating arterial thickness and calcification) (14). Echocardiographic studies have shown increased early left ventricular diastolic dysfunction and lower ejection fraction in PCOS $(\mathbf{2 0 , 2 1})$. Other studies demonstrated increased pulse wave velocity of the brachial artery and increased stiffness of both internal and external carotid arteries $(\mathbf{2 2 , 2 3 )}$. Alterations in both endothelium-dependent and independent vasodilator responses of the brachial artery in women with PCOS have been also reported (24-28). Further, morphological studies have shown that women with PCOS have increased carotid intima media thickness as well as higher incidence of coronary and aortic arterial calcification (29-32). These reports are complemented with angiographic data in women showing an association between coronary artery disease and polycystic ovaries (33).

\section{Changes in polycystic ovaries and androgens with age}

Several studies have shown that androgen secretion spontaneously decreases after the age of 35 in normal and PCOS women $(\mathbf{3 4 , 3 5 )}$ and that in the general population the prevalence of polycystic ovaries appears to decrease with age too (36). Further, women with polycystic ovaries may regain normal menses with age (37) and may also get spontaneous fertility (38). Therefore, the diagnosis of PCOS becomes less common with age and the syndrome shows lower alterations, including reduced androgen levels. 
The decrease of circulating androgens in women with PCOS during their late fertile age may play a role in the reduction of their cardiovascular risk. Interestingly, in a recent study that demonstrated an increased number of cardiovascular events in postmenopausal women with PCOS, a significant association was found between postmenopausal androgen levels and cardiovascular events (39). Therefore, androgens may play an important role on cardiovascular outcome and the development of vascular events may be influenced by the presence of androgen excess after menopause.

\section{Body weight and diabetes in post-menopausal age}

Early reports have suggested that women with PCOS may develop menopause at a later age than control women (40). Yet, more recent studies have shown that menopausal age is similar in women with or without PCOS (39). It has been reported that, at least in the USA, there is a greater morbidity of surgical menopause due to bilateral oopherectomy in women with clinical features of PCOS (39). Although there is still no clear explanation for this (uterine problems such as endometrial hyperplasia or fibromas ?), menopause at young age may play a role for the future life of these women (e.g., earlier appearance of cardiovascular disease, bone loss).

Further, it has been shown that postmenopausal women with PCOS have higher prevalence of obesity and type- 2 diabetes than postmenopausal controls $(\mathbf{3 9 , 4 0 )}$. Both disorders may contribute to the increase of cerebro-vascular and cardio-vascular events in this category of subjects (39). As previously reported, the increase of circulating inflammatory factors significantly influence the cardiovascular outcome in postmenopausal PCOS (39) and it is has been shown that this is linked to the role of the visceral adipose tissue (41). These findings suggest that body weight should be one of the main targets of the long-term treatment of PCOS (42). 


\section{Cardiovascular risk in post-menopausal age}

Main studies on cardiovascular outcome in women with PCOS are summarized in Table 1. With the term "cardiovascular" we refer to a generalized vascular disease which affects also the heart and not simply to atherosclerotic changes affecting the cardiac muscle. Initial studies on the prevalence of cardiovascular diseases in postmenopausal women, who were probably affected by PCOS during their fertile age, indicated an increased risk for developing myocardial infarction (3). It was calculated that women with PCOS have 7.1 higher risk to develop myocardial infarction than non-PCOS women (41). However, the number of the studied subjects was rather small (only 33 patients) and the authors did not found an increased cardiovascular morbidity but only an increased risk (41).

A later and larger study (786 postmenopusal women) did not demonstrate any difference in cardiovascular morbidity and mortality between women with PCOS and the general population (42). On the basis of the observed alterations in several markers of clinical and subclinical atherosclerosis, these results were somehow unexpected and suggested the absence of long term cardiovascular consequences of PCOS. However, this study has been criticized because the diagnosis of PCOS was based on historical data during a very large period (hospital records between 1930 and 1979) and was not supported by hormonal studies or ovarian morphology.

In a successive report, the same authors (43) studied a more restricted but carefully selected cohort of patients (309 postmenopausal women who were diagnosed as affected by PCOS before 1979 in the United Kingdom). The authors didn't show any increase in coronary heart disease (odd ratio 1.5) but found higher prevalence of cerebrovascular outcome (odd ratio 2.8). Interestingly, in the Framingham study the reported presence of oligomenorrhea 
during fertile years wasn't associated to cardiac events but to increased number of cerebrovascular events (44).

A recent study has shown that women with PCOS have increased prevalence of some cardiac events. In fact, studying a large group of postmenopausal women who underwent an angiographic study because of the suspect of myocardial ischemia, an adverse association between clinical and hormonal features of PCOS and cardiovascular outcome in a 6-year follow-up has been recently demonstrated (39). While other studies are needed to confirm and expand this study, it is clear that PCOS is associated to an increased risk for cerebrovascular events (stroke) and probably also for fatal and nonfatal coronary heart disease. In addition, this risk is more severe in patients having higher androgens but mostly presenting higher inflammatory factors in the blood. These findings are somewhat similar to those found in a cross-sectional study on old non-diabetic postmenopausal women where atherosclerotic cardiovascular events were associated with features of a putative PCOS phenotype (45).

\section{Conclusions}

We need many more studies on long term consequences of PCOS. The data are few and often conflicting. However, there is increasing evidence that postmenopausal women with PCOS have more cerebro-vascular events and probably cardiovascular morbidity too. This may be partially related to the persisting hyperandrogenism but is mostly related to the altered body weight (usually due to the visceral obesity). Therefore, one of the best long-term strategies is information, acknowledging women with PCOS of their high risk for metabolic and cardiovascular diseases. 


\section{REFERENCES}

1) Guzick DS. Cardiovascular risk in PCOS. J Clin Endocrinol Metab. 2004; 89:3694-5.

2) Lobo RA, Carmina E. The importance of diagnosing the polycystic ovary syndrome. Ann Intern Med. 2000; 132:989-93.

3) Legro RS. Polycystic ovary syndrome and cardiovascular disease: a premature association? Endocr Rev 2003; 24:302-12.

4) Kelly CC, Lyall H, Petrie JR, Gould GW, Connell JM, Sattar N. Low grade chronic inflammation in women with polycystic ovarian syndrome. J Clin Endocrinol Metab 2001;86:2453-5.

5) Boulman N, Boulman N, Levy Y, Leiba R, Shachar S, Linn R et al. Increased C-reactive protein levels in the polycystic ovary syndrome: a marker of cardiovascular disease. J Clin Endocrinol Metab 2004;89:2160-5.

6) Möhlig M, Spranger J, Osterhoff M, Ristow M, Pfeiffer AF, Schill T et al. The polycystic ovary syndrome per se is not associated with increased chronic inflammation. Eur $\mathrm{J}$ Endocrinol 2004;150:525-32.

7) Panidis D, Kourtis A, Farmakiotis D, Mouslech T, Rousso D, Koliakos G. Serum adiponectin levels in women with polycystic ovary syndrome. Hum Reprod 2003;18:1790-6.

8) Spranger J, Möhlig M, Wegewitz U, Ristow M, Pfeiffer AF, Schill T et al. Adiponectin is independently associated with insulin sensitivity in women with polycystic ovary syndrome. Clin Endocrinol 2004;61:738-46.

9) Sampson M, Kong C, Patel A, Unwin R, Jacobs HS. Ambulatory blood pressure profiles and plasminogen activator inhibitor (PAI-1) activity in lean women with and without the polycystic ovary syndrome. Clin Endocrinol 1996;45:623-9. 
10) Dahlgren E, Janson PO, Johansson S, Lapidus L, Lindstedt G, Tengborn L. Hemostatic and metabolic variables in women with polycystic ovary syndrome. Fertil Steril 1994;61:455-60.

11) Diamanti-Kandarakis E, Spina G, Kouli C, Migdalis I. Increased endothelin-1 levels in women with polycystic ovary syndrome and the beneficial effect of metformin therapy. $\mathrm{J}$ Clin Endocrinol Metab 2001;86:4666-73.

12) Loverro G, Lorusso F, Mei L, Depalo R, Cormio G, Selvaggi L. The plasma homocysteine levels are increased in polycystic ovary syndrome. Gynecol Obstet Invest 2002;53:157-62.

13) Sabuncu T, Vural H, Harma M. Oxidative stress in polycystic ovary syndrome and its contribution to the risk of cardiovascular disease. Clin Biochem 2001;34:407-13.

14) Cussons AJ, Stuckey BG, Watts GF. Cardiovascular disease in the polycystic ovary syndrome: new insights and perspectives. Atherosclerosis 2006; 185:227-39

15) Legro RS, Kunselman AR, Dunaif A. Prevalence and predictors of dyslipidemia in women with polycystic ovary syndrome. Am J Med 2001;111:607-13.

16) Berneis K, Rizzo M, Fruzzetti F, Lazzaroni V, Carmina E. Atherogenic lipoprotein phenotype and LDL size and subclasses in women with polycystic ovary syndrome. J Clin Endocrinol Metab 2007; 92:186-189.

17) Valkenburg O, Steegers-Theunissen RP, Smedts HP, Dallinga-Thie GM, Fauser BC, Westerveld EH et al. A more atherogenic serum lipoprotein profile is present in women with polycystic ovary syndrome: a case-control study. J Clin Endocrinol Metab 2008; 93:470-6.

18) Berneis K, Rizzo M, Hersberger M, Rini GB, Di Fede G, Pepe I, Spinas GA, Carmina E. Atherogenic forms of dyslipidemia in women with polycystic ovary syndrome. Int J Clin Pract In press 
19) Rizzo M, Berneis K. Low-density-lipoproteins size and cardiovascular risk assessment QJM - Int J Med 2006. 99: 1-14.

20) Tíras MB, Yalcìn R, Noyan V, Maral I, Yìldìrìm M, Dörtlemez O et al. Alterations in cardiac flow parameters in patients with polycystic ovarian syndrome. Hum Reprod $1999 ; 14: 1949-52$.

21) Orio F, Palomba S, Spinellli L, Cascella T, Tauchmanova L, Zullo F et al. The cardiovascular risk of young women with polycystic ovary syndrome: an observational, analytical, prospective case-control study. J Clin Endocrinol Metab 2004; 89:3696-3701

22) Kelly CJ, Speirs A, Gould GW, Petrie JR, Lyall H, Connell JM. Altered vascular function in young women with polycystic ovary syndrome. J Clin Endocrinol Metab 2002;87:7426.

23) Lakhani K, Constantinovici N, Purcell WM, Fernando R, Hardiman P. Internal carotid artery haemodynamics in women with polycystic ovaries. Clin Sci (Lond) 2000;98:661-5.

24) Tarkun I, Arslan BC, Cantürk Z, Türemen E, Sahin T, Duman C. Endothelial dysfunction in young women with polycystic ovary syndrome: relationship with insulin resistance and low-grade chronic inflammation. J Clin Endocrinol Metab 2004;89:5592-6.

25) Orio F Jr, Palomba S, Cascella T, De Simone B, Di Biase S, Russo T et al. Early impairment of endothelial structure and function in young normal-weight women with polycystic ovary syndrome. J Clin Endocrinol Metab 2004;89:4588-93.

26) Kravariti M, Naka KK, Kalantaridou SN, Kazakos N, Katsouras CS, Makrigiannakis A et al. Predictors of endothelial dysfunction in young women with polycystic ovary syndrome. J Clin Endocrinol Metab 2005;90:5088-95.

27) Diamanti-Kandarakis E, Alexandraki K, Protogerou A, Piperi C, Papamichael C, Aessopos A et al. Metformin administration improves endothelial function in women with polycystic ovary syndrome. Eur J Endocrinol 2005;152:749-56. 
28) Carmina E, Orio F, Palomba S, Longo RA, Cascella T, Colao A, et al. Endothelial dysfunction in PCOS: role of obesity and adipose hormones. Am $\mathrm{J}$ Med. 2006;119(4):356.e1-6.

29) Talbott EO, Guzick DS, Sutton-Tyrrell K, McHugh-Pemu K, Zborowski J, Remsberg K et al. Evidence for association between polycystic ovary syndrome and premature carotid atherosclerosis in middle-aged women. Arterioscler Thromb Vasc Biol 2000; 20:24142421.

30) Guzick DS, Talbott EO, Sutton-Tyrrell K, Herzog HC, Kuller LH, Wolfson SK Jr. Carotid atherosclerosis in women with polycystic ovary syndrome: initial results from a casecontrol study. Am J Obstet Gynecol 1996;174:1224-9.

31) Talbott EO, Zborowski JV, Rager JR, Boudreaux MY, Edmundowicz DA, Guzick DS. Evidence for an association between metabolic cardiovascular syndrome and coronary and aortic calcification among women with polycystic ovary syndrome. J Clin Endocrinol Metab 2004;89:5454-61.

32) Christian RC, Dumesic DA, Behrenbeck T, Oberg A, Sheedy PF, Fitzpatrick L. Prevalence and predictors of coronary artery calcification in women with polycystic ovary syndrome. J Clin Endocrinol Metab 2003; 88:2562-2568.

33) Birdsall MA, Farquhar CM, White HD. Association between polycystic ovaries and extent of coronary artery disease in women having cardiac catheterization. Ann Intern Med $1997 ; 126: 32-5$.

34) Labrie F, Belanger A, Cusan L, Gomez J, Candas B. Marked decline in serum concentrations of adrenal C19 sex steroid precursors and conjugated androgen metabolites during aging. J Clin Endocrinol Metab 1997; 82: 2396-2402 
35) Bili H, Laven J, Imani B, Eijkemans MJ, Fauser BC. Age-related differences in features associated with polycystic ovary syndrome in normogonadotrophic oligo-amenhorroeic infertile women of reproductive years. Eur J Endocrinol 2001; 145: 749-55

36) Koivunen R, Laatikainen T, Tomas C, Huhtaniemi I, Tapanainen J, Martikainen H. The prevalence of polycystic ovaries in healthy women. Acta Obstet Gynecol Scand 1999;78:137-41.

37) Elting MW, Korsen TJ, Rekers-Mombarg LT, Schoemaker J. Women with polycystic ovary syndrome gain regular menstrual cycles when ageing. Hum Reprod. 2000; 15:24-8

38) Vulpoi C, Lecomte C, Guilloteau D, L Lecomte P. Ageing and reproduction: is polycystic ovary syndrome an exception? Ann. Endocrinol (Paris) 2007; 68:45-50

39) Shaw LJ, Merz CN, Azziz R, Stanczyk FZ, Sopko G, Braunstein GD et al. PostMenopausal Women with a History of Irregular Menses and Elevated Androgen Measurements at High Risk for Worsening Cardiovascular Event-Free Survival: Results from the National Institutes of Health National Heart, Lung, and Blood Institute (NHLBI) Sponsored Women's Ischemia Syndrome Evaluation (WISE). J Clin Endocrinol Metab. 2008 Jan 8; [Epub ahead of print]

40) Dahlgren E, Johansson S, Lindstet G, Knutsson F, Oden A, Janson PO et al. Women with Polycystic Ovary Syndrome wedge resected in 1956-1965: a long-term follow-up focusing on natural history and circulating hormones. Fertil Steril 1992; 57: 505-13

41) Dahlgren E, Janson PO, Johansson S, Lapidus L, Oden A. Polycystic ovary syndrome and risk for myocardial infarction. Evaluated from a risk factor model based on a prospective population study of women. Acta Obstet Gynecol Scand 1992; 71:599-604.

42) Pierpoint T, McKeigue PM, Isaacs AJ, Wild SH, Jacobs HS.. Mortality of woman with polycystic ovary syndrome at long term follow up. J Clin Epidemiol 1998;51:581-86. 
43) Wild SH, Pierpoint T, Mckeigue PM, Jacobs HS. Cardiovascular disease in women with polycystic ovary syndrome at long-term follow-up: a retrospective cohort study. Clin Endocrinol 2000;52:595-600.

44) Dawber TR, Meadors GF, Moore FE Jr. Epidemiological approaches to heart disease: the Framingham Study. Am J Public Health 1951; 41:279-81

45) Cibula D, Cifkova R, Fanta M, Poledne R, Zivny J, Skibova J. Increased risk of noninsulin dependent diabetes mellitus, arterial hypertension and coronary artery disease in perimenopausal women with a history of the polycystic ovary syndrome. 2000 Hum Reprod 15:785-789. 
Table 1.

Long-term studies examining the prevalence of cardiovascular diseases in women with PCOS.

\begin{tabular}{|c|c|c|c|c|c|c|}
\hline $\begin{array}{l}\text { Authors } \\
\text { (year) }\end{array}$ & Study design & $\begin{array}{l}\text { n. of } \\
\text { PCOS }\end{array}$ & $\begin{array}{l}\text { Mean age, } \\
\text { years }\end{array}$ & PCOS definition & Results & Cardiovascular end points \\
\hline $\begin{array}{l}\text { Dahlgren } \\
\text { (1992) }\end{array}$ & population study & 33 & $50(40-59)$ & $\begin{array}{l}\text { Histopathology typical of PCOS at } \\
\text { wedge resection }\end{array}$ & Positive & $\begin{array}{l}\text { increased risk (relative risk of } 7.4 \text { ) of } \\
\text { developing myocardial infarction in PCOS } \\
\text { compared to age-matched women }\end{array}$ \\
\hline $\begin{array}{l}\text { Pierpoint } \\
\text { (1998) }\end{array}$ & population study & 786 & $\begin{array}{l}>45 \text { at the time } \\
\text { of follow-up }\end{array}$ & $\begin{array}{l}\text { Histological evidence of PCOS or } \\
\text { macroscopic evidence of ovarian } \\
\text { dysfunction or clinical diagnosis }\end{array}$ & Negative & $\begin{array}{l}\text { no difference in cardiovascular deaths } \\
\text { between PCOS rates and national rates in a } \\
\text { mean follow-up period of } 30 \text { years }\end{array}$ \\
\hline $\begin{array}{l}\text { Wild } \\
(2000)\end{array}$ & population study & 678 & $\begin{array}{l}<75 \text { at the time } \\
\text { of follow-up }\end{array}$ & $\begin{array}{l}\text { Histological evidence of PCOS or } \\
\text { macroscopic evidence of ovarian } \\
\text { dysfunction or clinical diagnosis }\end{array}$ & Negative & $\begin{array}{l}\text { no difference in cardiovascular morbidity } \\
\text { and mortality compared to age-matched } \\
\text { women }\end{array}$ \\
\hline $\begin{array}{l}\text { Cibula } \\
(2000)\end{array}$ & Cross-sectional & 28 & $52 \pm 5$ & $\begin{array}{l}\text { Wedge ovarian resection for typical } \\
\text { clinical and morphologican } \\
\text { symptoms of PCOS }\end{array}$ & Positive & $\begin{array}{l}\text { Increased coronary artery diseases in PCOS } \\
\text { in relation to age- and BMI-matched } \\
\text { women }\end{array}$ \\
\hline $\begin{array}{l}\text { Elting } \\
\text { (2001) }\end{array}$ & population study & 346 & $39(30-56)$ & $\begin{array}{l}\text { oligo- or amenorrhoea and increased } \\
\text { LH with normal FSH }\end{array}$ & Negative & $\begin{array}{l}\text { no difference in cardiac events in relation to } \\
\text { age-matched women }\end{array}$ \\
\hline $\begin{array}{l}\text { Talbott } \\
(2004)\end{array}$ & prospective & 127 & $35 \pm 8$ & $\begin{array}{l}\text { History of chronic anovulation and } \\
\text { hirsutism }\end{array}$ & Positive & $\begin{array}{l}\text { increased risk (relative risk of 5.9) of } \\
\text { developing cardiovascular events in PCOS } \\
\text { compared to age-matched women }\end{array}$ \\
\hline $\begin{array}{l}\text { Krentz } \\
(2007)\end{array}$ & Cross-sectional & 64 & $78 \pm 8$ & $\begin{array}{l}\text { irregular menses, hyperandrogenism, } \\
\text { infertility, central obesity, insulin } \\
\text { resistance }\end{array}$ & Positive & $\begin{array}{l}\text { association between PCOS and } \\
\text { cardiovascular diseases in non-diabetic } \\
\text { post-menopausal women }\end{array}$ \\
\hline $\begin{array}{l}\text { Shaw } \\
(2008)\end{array}$ & $\begin{array}{l}\text { Prospective, } \\
\text { multi-center }\end{array}$ & 104 & $63 \pm 10$ & $\begin{array}{l}\text { premenopausal history of irregular } \\
\text { menses and current biochemical } \\
\text { evidence of hyperandrogenemia. }\end{array}$ & Positive & $\begin{array}{l}\text { association between clinical features of } \\
\text { PCOS and cardiovascular outcomes in a 5- } \\
\text { year follow-up }\end{array}$ \\
\hline
\end{tabular}

